\title{
Peer Influence and Performance Task of Senior High School Students
}

\author{
Jerald C. Moneva ${ }^{1}$ \& Fatima Legaspino ${ }^{2 \#}$ \\ 1,2 Jagobiao National High School, Jagobiao, Mandaue City, Cebu, Philippines.
}

\# corresponding author

Type of Work: Peer-Reviewed

DOl: http://dx.doi.org/10.21013/jems.v16.n1.p11

\section{How to cite this paper:}

Moneva, J.C., Legaspino, F. (2020). Peer Influence and Performance Task of Senior High School Students. IRA International Journal of Education and Multidisciplinary Studies (ISSN 2455-2526), 16(1), 76-83. doi: http://dx.doi.org/10.21013/jems.v16.n1.p11

(C) Institute of Research Advances.

This work is licensed under a Creative Commons Attribution-Non Commercial 4.0 International License subject to a proper citation to the publication source of the work.

Disclaimer: The scholarly papers as reviewed and published by the Institute of Research Advances (IRA) are the views and opinions of their respective authors and are not the views or opinions of the IRA. The IRA disclaims of any harm or loss caused due to the published content to any party.

Institute of Research Advances is an institutional publisher member of Publishers International Linking Association Inc. (PILA-CrossRef), USA. The institute is an institutional signatory to the Budapest Open Access Initiative, Hungary advocating the open-access of scientific and scholarly knowledge. The Institute is a registered content provider under Open Access Initiative Protocol for Metadata Harvesting (OAI-PMH).

The journal is indexed \& included in WorldCat Discovery Service (USA), CrossRef Metadata Search (USA), WorldCat (USA), OCLC (USA), Open J-Gate (India), EZB (Germany) Scilit (Switzerland), Airiti (China), Bielefeld Academic Search Engine (BASE) of Bielefeld University, Germany, PKP Index of Simon Fraser University, Canada. 


\begin{abstract}
The Peer group is composed of equal status, where students within a given peer group are of the same age and have the same social status. The performance task is any learning activity or assessment that asks students to perform to demonstrate their knowledge, understanding, and proficiency. Performance tasks as part of the student's performance in school, probably this might be influenced by peers of the students. The study used a descriptive design to determine the influence of peer on the performance task of the students. A total of 243 Senior High students of Jagobiao National High School answered the Likert scale questionnaire, an instrument used by the researcher to conduct the study. The study used weighted mean and chi-square to determine whether peer influence has an association with students' performance tasks. The results show that peers can influence students' performance tasks. It was shown in the study that students get a low grade from skipping classes together with their peers. The study concluded that there is an association between peer influence and academic performance of the students. Therefore, peer plays a big role in student's academic engagement and academic success.
\end{abstract}

Keywords: Peer influence, Peer group, Performance task, Senior high students

\title{
Introduction
}

Peers are the people in which you have a close relationship with each other and they have regular interactions. They share views, opinions, and exchange ideas with each other and do activities together. Peer group composed of equal status, that all students within a given peer group are of the same age, and came from the same social status. Somehow, peer influence affects the performance of the students either inside or outside the school campus. Performance tasks as part of the student's performance in school, probably this might be influenced by peers of the students. However, this was still in a process of inquiry.

The performance task is any learning activity or assessment that asks students to perform to demonstrate their knowledge, understanding, and proficiency. Performance task senses as evidence of learning. Some students, somehow, having a lower performance task than the others. Furthermore, the performance task is one of the basic computing student's grades that symbolize how well the students perform in school. This task is being used in every subject area and at all grade levels.

The Peer group is one of the factors that can affect the students' learning process [1]. Peers can offer a feeling of motivation to learners and assist learners to see how important achievements to pursue [2]. A peer group increases its value and worth if they give help and assistance in the right direction [3].

In Jagobiao National High School, it has been observed that students belong to a specific peer group. This peer group might help the students to improve their work on the performance task. Also, it is one of the sources of motivation for some students in doing well on their tasks. This study aims to examine the relationship between peer influence and performance tasks. This research paper specifically focuses on how peer influence is related to the performance task.

\section{Statement of the Problem}

The study intends to determine the association of peer influence and performance tasks of Senior High students. Especially, the study seeks to know about the level of peer influence of senior high students, the level of performance task of the students in their task and the association between the peer influence and performance task of senior high students.

Null: There is no association between the peer influence and performance task of Senior High students. Alternative: There is an association between the peer influence and performance task of Senior High students.

\section{Related Review of Literature}

The interaction in the group determined to some extent by the personal characteristics of each group member. The group is influenced only to a degree by its members regardless of behaviors exhibited by each individual; the group develops behavior on its own. Therefore, this chapter of the research work will focus on giving a clear 
understanding of the issue of peer influence of the students. Peer influence has factors that affect adolescent behavior positively and negatively [4]. Peers may help students to encourage and engage their selves towards academic success [2]. Besides, Peers may also influence adolescent decision making due to the changes of their brain's reward system as they go through adolescence in contrast to the immaturity of their cognitive control which associates with each other in a complex manner [5].In the aspect of selecting schools, parents decide better than their children's decisions [3].

Students having positive engagement with peers who value education will have a positive effect on influencing students in their academic activities [6]. Concerning this, the interaction between children and their peers affects their learning capacity positively and negatively [1]. Gender differences during mid-adolescence were most pronounced when girls were more resistant to peer influence than boys [7]. Students are more susceptible to influence from close friends who are similar to them in history or school experiences, friends who have different gender and are not mutual in their choices are less influential than friends that are similar to each other [8]. A friend with the same gender influences a teenager to change his or her level of risk activity, teenagers are more likely to influence by their friends who participated in a risk activity [9]. Besides, the perceived parental and peer attachment of late adolescent college students showed considerable variation, and the two forms of attachment were significantly associated. Therefore, low levels of parental and peer attachment put students at risk of academic failure and inadequate psychosocial skills [10]. Peer influence contributed an important way to the psychosocial functioning as well as the performance of the students in the secondary schools (private and government) peer group affects adolescent students' academic performance positively and negatively [11].

A person together with his or her peers \& friends performs a higher activity intensity while spending alone results in less intense activity [12]. Peer relationships can also promote a positive influence as children of different levels of ability begin to work together. Educational similarities among peers in the classroom can enhance students' academic performance [13]. Peer encouragement was linked positively to student grades. Supportive peer relationships also promote rather than discourage achievement for African American youth, they provide a more positive view of African American peer groups that are often represented concerning academic achievement in a primarily negative light [14]. On the other hand, peer influence helps reduce hyperactivity in the classroom, but it has not been investigated for its effect on academic achievement [15].

Student academic performance was substantially related to measuring competence and academic competence [16]. Many parents have a disparity between the past academic performance of students and future parental expectations. Parents with unrealistic expectations about the future performance of their children may find it difficult to know what they can do to improve the academic potential of their children [17].In academic performance, 4 factors can affect the student's performance in school. Communication, learning facilities, proper guidance shows a positive impact on student performance. While family stress shows a negative impact on the students' performance [18]. The use of social media had affected the academic performance of the students because the majority of them have a mobile phone with internet access and having knowledge of the existence of social media sites. It also confirms that the use of social media and the academic performance of the students are strongly associated [19]. Sleepiness found no significant improvements in the ability to learn and maintain new information amidst having a few hours of sleep [20].

Students who have a high risk of procrastination are academically low average while students who are fewer procrastinators are academically above average in their performances [21]. Other predictors of academic performance include components such as age, course, and a history of failures as well as residence. GPA, sex, and emotional intelligence are the best predictors of students' academic performance [22].The parents' level of income on the students' academic achievement. Parents also have a vital role to play in improving their children's academic achievement by offering the social, financial and material support they need to encourage their children to succeed at school [23]. Students essentially improve their home environment and study habits such as giving adequate study time, proper revision of lecture notes, avoiding activities interfering with the planned study schedule, then their learning skills such as presentation skills, reading material related to course content in addition to lecture notes and academic interaction with fellow students [24].

Self-esteem at a high level leads to good academic performance. Female students are found to have higher academic performance compared to men. It was also observed that the self-esteem of male students was higher compared to 
female students [25]. Among 200 nursing students, there is no statistically significant correlation among male and female anxiety and their academic performance. This means that gender has no major role to play in deciding nursing students' level of anxiety and academic performance [26]. The academic performance of peers has a powerful explanatory power for an individual's academic performance. The evidence shows the strongest associations across various channels of social interactions with calls and text messages, further reinforcing the phenomenon [27].

\section{Methodology}

\section{Design}

The study is a descriptive research study. The study design seeks descriptive information on the influence of peer influence on the performance task of Senior High School students.

\section{Locale}

The survey will be conducted in Jagobiao National High School- Senior High. The Senior High Department has 2 buildings: (1) has 4 classrooms; and (2) has 4 classrooms used by students. These classrooms are composed of the following strands: Accountancy, Business and Management (ABM), Humanities and Social-Sciences (HUMSS), General Academic Strand (GAS), Science, Technological, Engineering, and Mathematics (STEM), and TechnicalVocational and Livelihood-TechnicalDrafting (TVL-TD).

\section{Respondents}

The study that the researcher made will be answered by all Senior High students. A total of 243 respondents are chosen because they are qualified to answer about peer influence and performance tasks.

\section{Instrument}

The main instrument used for the study surveyed the questionnaire-Likert scale, which was composed of two parts. Part one contained questions on the peer influence of the students. While part two contained another set of questions about the performance task of the students.

The questionnaire was scaled on the 4-point scale of Strongly Agree (SA), Agree (A), Strongly Disagree (SD), and Disagree (D). The respondents were asked to indicate the extent of their agreement with the given items.

\section{Data Gathering Procedure}

The researcher will ask permission from the school head by using a transmittal letter. The respondents will be given a questionnaire. The researcher will give them enough time to answer the questions. Then, the researcher will give their appreciation to the respondents for their cooperation. The data gathered by the researcher will be used for the analysis, interpretation, findings, conclusion, and recommendation of the study.

\section{Statistical Treatment}

The weighted mean and chi-square are used in this research study. A weighted mean is used to identify the mean of each questionnaire and chi-square is used to determine the significance of each variable of the study.

\section{PRESENTATION OF DATA, ANALYSIS, AND INTERPRETATION OF DATA}

This chapter presents and showcases the data been gathered, it also shows the analysis and interpretation of data. The purpose of this study was to identify if there is a significant relationship between peer influence and performance tasks of Senior High students in Jagobiao National High School. 
TABLE 1: PEER INFLUENCE

\begin{tabular}{lccc}
\hline & INDICATORS & W/M & INTERPRTIONS \\
\hline 1 & I belong to a peer group & 1.68 & Strongly Disagree \\
2 & I spend much time with my peer group & 1.95 & Disagree \\
3 & My peers have assisted me in improving my grades & 1.92 & Disagree \\
4 & I can make academic decisions easily when I am with my peers. & 1.86 & Disagree \\
5 & We study together after class. & 2.42 & Disagree \\
6 & We always help each other with academic difficulties. & 1.78 & Disagree \\
7 & My current achievement in all my subjects is better than the previous & 2.18 & Disagree \\
8 & one before I met my friends. & 3.22 & Agree \\
9 & I often skip classes to spend time with my friends. & 2.21 & Disagree \\
1 & The competition with my peers for grades is quite intense. & 2.58 & Agree \\
0 & I and my friends are always talking every class hours. & 2.77 & Agree \\
1 & I and my friends compete for grades. & 2.79 & Agree \\
1 & My peers destruct me in my studies. & $\mathbf{2 . 2 8}$ & DISAGREE \\
2 & Overall Weighted Mean & Strongly Agree (3.26-4).
\end{tabular}

The result above shows that the overall weighted mean of peer influence is 2.28

signifies that students disagreed that their peers don't help them to improve their grades. The statements, I often skip classes to spend time with my friends, my peers destruct me on my studies, I and my friends compete for grades, are the indicators with the highest weighted mean of 3.22, 2.79 and 2.77, respectively, which has an interpretation of agreed. While the statements, I belong to a peer group, we always help each other with academic difficulties, I can make academic decisions easily when I am with my peers, are the indicators with a lower weighted mean of 1.68 , 1.78 and 1.86, respectively, with an interpretation of disagreed. A student who has a peer with high academic attainment increase their school engagement [2]. Students who are not interested in their studies become study inclined if they belong in a group that encourages them to have effective learning [1]. Peers play a big role in affecting student's decision making [3].

Peer Influence

\begin{tabular}{ccccc}
\hline & Frequency & Percent & Valid Percent & $\begin{array}{c}\text { Cumulative } \\
\text { Percent }\end{array}$ \\
\hline Not Influential & 0 & 0 & 0 & 0 \\
Slightly Influential & 70 & 28.8 & 28.8 & 28.8 \\
Moderately Influential & 158 & 65.0 & 65.0 & 93.8 \\
Highly Influential & 14 & 5.8 & 5.8 & 99.6 \\
\hline Total & 243 & 100.0 & 100.0 & \\
\hline
\end{tabular}

The table above shows the frequency of peer influence on the students. The level with the highest number of students is the average level consist of 158 students which is $65.0 \%$ while the level with the lowest number is not influential which is consist of 0 number of the student which is equal to $0 \%$. This shows that most of the students were not influenced by their peers. 
Table 2 Performance Task

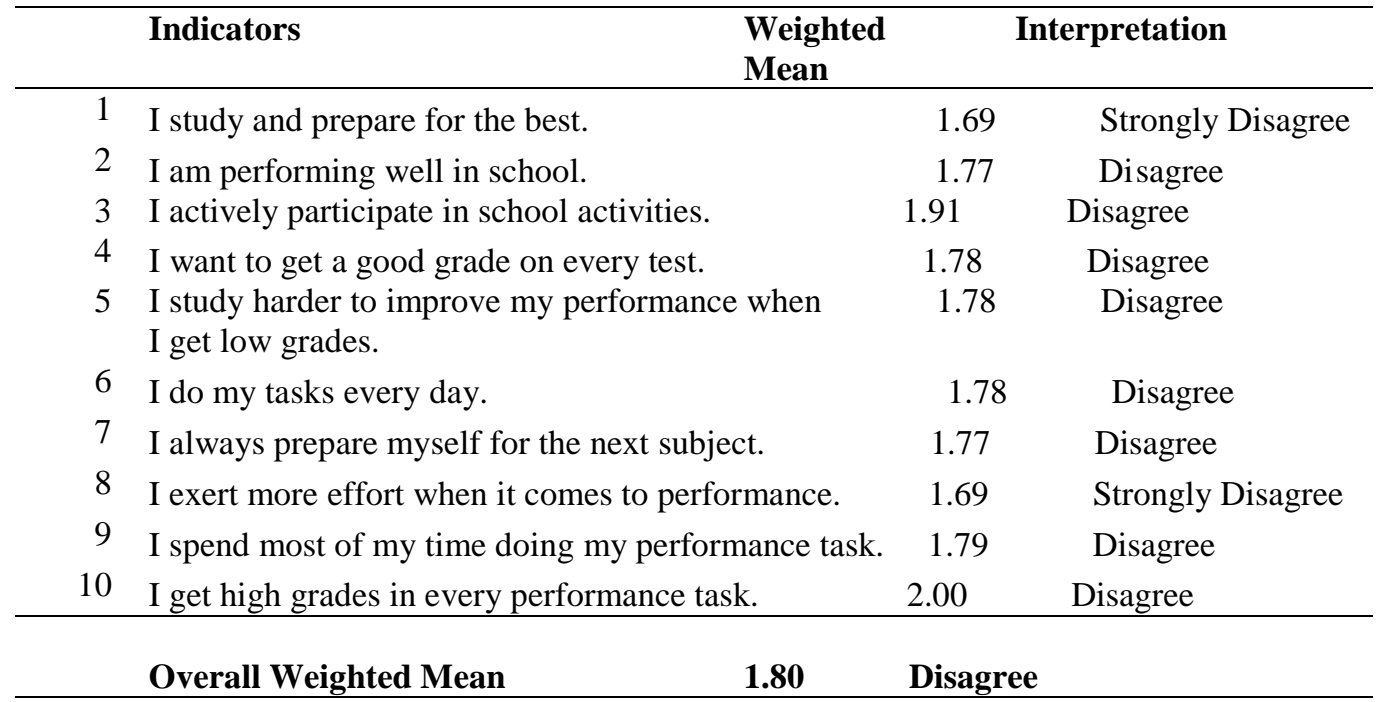

Legend: N=243 Strongly Disagree (1-1.75) Disagree (1.76-2.5) Agree (2.51-3.25) Strongly Agree (3.26-4).

The table above shows that the overall weighted mean of performance task is 1.80 which signifies that students disagreed that they have a high grade in their performance task. The statements, I get high grades in every performance task, I actively participate in school activities, I spend most of my time doing my performance task, are the indicators with the highest weighted mean of 2.00,1.91 and 1.79, respectively, which has an interpretation of disagree. While the statements, I study and prepare for the best, I exert more effort when it comes to performance, I always prepare myself for the next subject, are the indicators with a lowest weighted mean of 1.69, 1.69 and 1.77, respectively, which has an interpretation of strongly disagree. Being academically competent is an important factor that associates with the high academic performance [16]. Effort is the key determinant of academic success and it can be controlled over time [17]. Students develop their study habits through proper study time, presentation skills and reading lesson-related material [24].

\section{Performance Task}

\begin{tabular}{|c|c|c|c|c|}
\hline & Frequency & Percent & alid Perc & lative Percent \\
\hline Poor & 17 & 7.0 & 7.0 & 7.0 \\
\hline Average & 160 & 65.8 & 65.8 & 72.8 \\
\hline High & 59 & 24.3 & 24.3 & 97.1 \\
\hline Excellent & 7 & 2.9 & 2.9 & 100.0 \\
\hline Total & 243 & 100.0 & 100.0 & \\
\hline
\end{tabular}

The table above shows the frequency of the student's performance task. The level with the highest number of responses is the average with 160 responses which is equivalent to $65.8 \%$ while the level with the lowest number of responses is excellent with 7 number of responses which is equivalent to $2.9 \%$. This shows that most of the student's grade is average. 
Table 3

\begin{tabular}{llll}
\hline & Peer Influence and Performance Task & \\
\hline & Value & df & Asymp. Sig(2-sided) \\
\hline Pearson Chi-Square & $9.832 \mathrm{E}^{\mathrm{a}}$ & 700 & .000 \\
Likelihood Ratio & 462.668 & 700 & 1.000 \\
Linear-by-Linear Association & 17.756 & 1 & .000 \\
N of Valid Cases & 243 & & \\
\hline
\end{tabular}

a. 754 cells $(100.0 \%)$ have expected count less than 5 . The minimum expected count is .00 .

There is a significant association between the variables peer influence and performance task of Senior High students because the significant value is .000 which is lesser than the alpha $=0.05$. A negative strong relationship between peer influence and performance task was revealed. This means that the peer influence of students is having a significant correlation with the performance task of students in the negative aspect. Peer group with which a child interacts certainly has an impact on the performance task of the students [1]. The academic accomplishments of students are due to the effect of their peer group [3]. If the peer group was interested in studying hard and doing well, their fellow teenage students would possibly be motivated to perform better [11].

\section{Findings}

The result of this study reveals the level of peer influence and performance tasks of Senior High students. It shows that there is a negative association between peer influence and performance tasks of Senior High Students. The study shows that peers can influence a student's engagement in class. This means that the peer has a negative influence on the students. It shows from the results that peer destruct the students in their studies. Students were disagreeing that they get a high grade in every performance task and they are not active in class. The results show that students' performance task can be influenced by their peers. The study shows that there is a significant association between the variables peer influence and performance task of Senior High students. The results show that peers can influence the students' performance tasks negatively. This means that if the peers have a negative action, the students can influence, or vice versa. A strong relationship between peer influence and performance task was revealed.

\section{Conclusion}

Peers have the most influential factor that affects the students' behavior and actions positively or negatively. Students spend a lot of time being with their peers particularly in a school that can also give an impact on their behavior in school during class. The performance of students also reflects of what behavior and actions they show in school. Most of the respondents disagree that they get a high grade in their task because of the influence of their peer group. Also, the study concluded that peer influence truly gives a negative impact and has an association with the performance task.

\section{References}

[1] Olalekan, A. B. (2016). Influence of peer group relationship on the academic performance of students in secondary schools (A case study of selected secondary schools in Atiba local government area of Oyo State). Global Journal of Human-Social Science: A Arts\& Humanities- Psychology, 16(4). Retrieved from: https://pdfs.semanticscholar.org/288f/c56d2a6eb36ed11a35c474c4e41424074a10.pdf

[2] You, S. (2011). Peer influence and adolescents' school engagement. Procedia Social and Behavioral Sciences, 829835. DOI: 10.1016/j.sbspro.2011.11.311.

[3] Hussian, S., Ali, R., Zaman, A., Ghaffar, A., Aamir, S. \&Minaz, M. (2013). The impact of peer groups on the academic achievements of secondary school students. Journal of American Science, 9(11), 13-16. Retrieved from: https://www.academia.edu/13386456/The_Impact_Of_Peer_Groups_On_The_Academic_Achievements_Of_Secondar y_School_Students

[4] Padilla-Walker, L. \& Bean, R. (2009). Negative and positive peer influence: relations to positive and negative behaviors for American, European American, and Hispanic adolescents. Journal of Adolescence, 32, 323-337. DOI: 10. 1016lj.adolescence.2008.02.003 
[5] Albert, D., Chein, J. \& Steinberg, L. (2013). The teenage brain: Peer influences on adolescent decision making. Current Directions in Psychological Science, 22(2), 114-120. Retrieved from: https://link.springer.com/chapter/10.1007/978-14419-1268-8_11

[6] Stewart, E. (2008). School structural characteristics, student effort, peer associations, and parental involvement: The influence of school-and individual-level factors on academic achievement. Education and Urban Society, 40(2), 179204. DOI: $10.1177 / 0013124507304167$

[7] Sumter, S., Bokhorst, C., Steinberg, L. \&Westernberg, M. (2009). The developmental pattern of resistance to peer influence in adolescence: Will the teenager ever be able to resist? Journal of Adolescence, 32, 1009-1021. DOI: 10.1016/j.adolescence.2008.08.010.

[8] Hallinan, M. \&Williams, R. (2016). Students' characteristics and the peer influence Process. American Sociological Association, 63(2), 122-132. Retrieved from: https://www.jstor.org/stable/2112858

[9] Maxwell, K. (2002). Friends: the role of peer influence across adolescent risk behaviors. Journal of Youth and Adolescence, 31 (4), 267-277. DOI: 0047-2891/02/0800-0267/0

[10] Fass, M. \& Tubman, J. (2002). The influence of parental and peer attachment on college students' academic achievement. Psychology in the Schools, 39 (5), 185-195. DOI: 10.1002/pits.10050.

[11] Mosha, M. (2017). The influence of peer group on academic performance of adolescent students in secondary schools in Tanzania. Research Journal of Educational Studies and Review, 3(11), 18-26. Doi: 10. 67563.ujer735489

[12] Salvy, S.J. et.al. (2008). Peer influence on children's physical activity: an experience sampling study. Journal of Pediatric Psychology, 33(1), 33-49. DOI: 10.1093/jpepsy/jsmo39

[13] Delay, D. et.al. (2016). Peer influence on academic performance: A social network analysis of social-emotional intervention. Pre Sci, 12(2), 165-171. Retrieved from: https://link.springer.com/article/10.1007/s11121-016-0678-8

[14] Gonzales, N., Cause, A.M., Friedman, R.\& Mason, C. (1996). Family, peer, and neighborhood influences on academic achievement among African- American Adolescents: One-Year Prospective Effects. American Journal of Community Psychology, 24(3), 366-384. Retrieved from: https://link.springer.com/article/10.1007/BF02512027

[15] Evans, G. \&Oswalt, G. (1967). Acceleration of academic progress through the manipulation of peer influence. Bureau of Child Research \& Parsons State Hospital and Training Center, 6, 189-195. Retrieved from: https://www.sciencedirect.com/science/article/abs/pii/0005796768900065

[16] Sansgiry, S., Bhosle, M. \& Sail, K. (2006). Factors that affect academic performance among pharmacy students. American Journal of Pharmaceutical Education, 70(5). Retrieved from: https://www.ncbi.nlm.nih.gov/pmc/articles/PMC1637000/

[17] Yamamoto, Y. \&Holloway, S. (2010). Parental expectations and children's academic performance in a socio-cultural context. Educational Psychology Review, 22, 189-214. DOI: 10.1007/s10648-010-9121-z.

[18] Mushtaq, I. \& Nawaz Khan, S. (2012). Factors affecting students' academic performance. Global Journal of Management and Business Research, 12(9). DOI: 10.1234.8448494

[19] Owusu-Acheaw, M. \& Larson, A. G. (2015). Use of social media and its impact on academic performance of tertiary institution students: A study of students of Koforidua Polytechnic, Ghana. Journal of Education and Practice, 6(6). Retrieved from: https://eric.ed.gov/?id=EJ1083595

[20] Rodrigues, R.N., Viegas, C. A., Silva, A. A. \& Tavares, P. (2002). Daytime sleepiness and academic performance in medical students. ArqNeuropsiquiatr, 60(1), 6-11. Retrieved from: http://www.scielo.br/scielo.php?pid=S0004282X2002000100002\&script=sci_arttext

[21] Lakshminarayan, N., Potdar, Shrudha. \& Reddy, S. G. (2012). Relationship between procrastination and academic performance among a group of undergraduate dental students in India. Journal of Dental Education, 77(4), 524-528. Retrieved from: http://www.jdentaled.org/content/77/4/524.short

[22] Looyeh, H. R., Fazelpour, S. F.S., Masoule, S. R., Chehrzad, M. M. \&NejadLeili, E. K. (2017). The relationship between the study habits and the academic performance of medical sciences students. Journal of Holistic Nursing and Midwifery, 27(2), 65-73. DOI: 10.18869/acadpub.hnmj.27.2.65

[23] Machebe, C. H., Ezegbe, B. \&Onuoha, J. (2017). The impact of parental level of income on students' academic performance in high school in Japan. Universal Journal of Educational Research, 5(9),1614-1620. Retrieved from: https://eric.ed.gov/?id=EJ1170144

[24] Shahzadi, E. \& Ahmad, Z. (2011). A study on the academic performance of university students. International Conference on Recent Advances in Statistics, 255-268. DOI: 10.13140/2.1.3949.3126

[25] Arshad, M., Haider Zaidi, S. M. I. \& Mahmood, K. (2015). Self- esteem \& academic performance among university students. Journal of Education and Practice, 6(1). Retrieved from: https://files.eric.ed.gov/fulltext/EJ1083788.pdf

[26] Afolayan, J., Donald, B., Onasoga, O., Babafemi, A. \& Juan, A. (2013). Relationship between anxiety and academic performance of nursing students, nigerdelta university, Bayelsa state,Nigeria. Pelagia Research Library, 4(5), 25-33. DOI: $10.1166 / 097865435$

[27] Kassarnig, V., Mones, E., Bjerre-Nielson, A., Sapiezynski, P., Dreyer Lassen, D. \& Lehmann, S. (2018). Academic performance and behavioral patterns. EPJ Data Science Springer Open Journal, 7(10). Retrieved from: https://link.springer.com/article/10.1140/epjds/s13688-018-0138-8 